\title{
Hemşirelerin Psikososyal Sorunlarının ve Stresle Başa Çıkma Tarzlarının İncelenmesi
}

\author{
Nazmiye Güngör ${ }^{1}$ Sevgi Nehir ${ }^{2 *}$ \\ ${ }^{1}$ Menemen Devlet Hastanesi İzmir, Türkiye \\ ${ }^{2}$ Manisa Celal Bayar Üniversitesi Sağlık Bilimleri Fakültesi, Ruh Sağlığı ve Hastalıkları Hemşireliği Manisa, \\ Türkiye
}

email: sevgiturkmen2012@gmail.com,nzmygngr@gmail.com

Orcid:0000-0003-1761-786X

Orcid:0000-0002-3070-8718

*Sorumlu Yazar / Corresponding Author: Sorumlu Yazar: Sevgi Nehir

Gönderim Tarihi / Received: 02.04.2019

Kabul Tarihi / Accepted: 08.08.2019

DOI: $10.34087 /$ cbusbed.548466

\begin{abstract}
Amaç: $\mathrm{Bu}$ çalışma hemşirelerin psikososyal sorunlarının ve stresle başa çıkma tarzlarının belirlenmesi amacıyla yapild1.

Gereç ve Yöntem: Tanımlayıcı tipte planlanan çalışma, Nisan 2018 - Haziran 2018 tarihleri arasında Menemen Devlet Hastanesinde yürütüldü. Çalışmanın örneklemini bu hastanede görev yapan toplam 184 hemşire oluşturdu. Verilerin toplanmasında, Kişisel Bilgi formu, Hastane Anksiyete Depresyon Ölçeği (HAD) ve Stresle Başa Çıkma Tarzları Ölçeği kullanıldı. Verilerin analizinde sayı yüzde, Mann Whitney U, Kruskal Wallis testi ve Spearman korelasyon analizi yöntemlerine başvuruldu.

Bulgular: Araştırmada hemşirelerin \%94'ünün kadın, \%52,7'sinin 39 yaş ve üstü, \%62,5'inin lisans ve lisansüstü, $\% 82,6$ 'sının mesleğini severek yaptığı belirlendi. Hemşirelerin yaş grupları eğitim, hastalığa sahip olma, mesleği severek yapma, çalıştıkları birimden memnun olma, psikososyal desteğe ihtiyaç duyma durumları ile stresle başa çıkma tarzı arasında anlamlı fark olduğu belirlendi $(\mathrm{p}<0,05)$. Hemşirelerin psikososyal sorunlarında artış olması stresle baş etme alt boyutlarında; kendine güvenli yaklaşım, iyimser yaklaşım ve sosyal destek arama yaklaşımı alt boyut puanlarında azalma olduğu, kendine güvensiz yaklaşım ve boyun eğici yaklaşım alt boyut puanlarında ise artış olduğu belirlendi.
\end{abstract}

Sonuç: Hemşirelerin zor bir gruba hizmet vermesinden dolayı yıpranma durumları değerlendirilebilir. Hemşireler mümkün olduğunca severek ve huzurlu çalıştıkları yerlerde istihdam edilmelidir.

Anahtar Kelimeler: Anksiyete, Depresyon, Stresle Başa Çıkma, Hemşire.

\footnotetext{
Abstract

Objective: This study was carried out to determine the psychosocial problems of nurses and their coping strategies with stress.

Methods: The study was conducted as a descriptive study in Menemen State Hospital from April 2018 to June 2018. The study samples consisted of 184 nurses who are working at that hospital Personal information form, The Hospital Anxiety and Depression Scale (HADS), and Ways of Coping Stress Inventory were used for data collection. Percentages, Mann Whitney U test, Kruskal Wallis test and Spearman correlation analysis were used in the data evaluation.

Results: In the study, it was determined that $94 \%$ of them were women, $52.7 \%$ were 39 years

old and over, $62.5 \%$ were undergraduate and graduate; $82.6 \%$ of them said they liked their profession. It was determined that there was a statistically significant difference between coping strategies with stress and age groups, having illness, having pleasure in the profession,

being satisfied with the unit they were working in, and needing psychosocial support $(\mathrm{p}<0,05)$. It was determined that the increase in psychosocial problems of nurses is due to stress coping subfields; self-confident approach, optimistic approach and searching social support approach subscale scores decreased, self-insecure approach and submissive approach subscale scores increased.
} 
Conclusion: Since the nurses serve a difficult group, psychological wear should be evaluated. Nurses should be employed in clinics where they can be happy and peaceful while working as much as possible.

Keywords: Anxiety, Coping With Stress, Depression, Nursing.

\section{Giriș}

Çalışma yaşamına katılan bireylerin beden ve ruh sağlığını sürdürebilmesi, fizyolojik, toplumsal ve kurumsal kaynaklı olumsuz etmenlerden korunması ile mümkündür. Çalışma yaşamı ve kişisel yaşam ayrılmaz bir bütündür ve birbirleri ile etkileşim halindedir. $\mathrm{Bu}$ etkileşimin pozitif yönde olması, bireyin sağlı̆̆ına ve çalıştığı kurumun başarısına katkı sağlamaktadır [1, 2].

Hastanelerde görevli sağlık personelleri için çalışma koşulları, şekli ve fiziki ortam büyük önem taşımaktadır. İşin, kurum içindeki yapısı ve nasıl yönetildiğine göre değişen sosyal, çevresel ve kurumsal etkileri nedeniyle fiziksel, psikolojik, sosyal ve kurumsal zararlar içerebilir. Çalışma yaşamı, iş yükünün ve çalışma yoğunluğunun fazlalığı, mesai saatlerinin uzunluğu, iş güvencesinin yetersizliği ve idarenin eksik veya yanlış tutumları nedeniyle çalışanların sağlığını olumsuz olarak etkilemektedir $[1,2]$.

Sağlık kurumları, stres altında olan hasta bireylere ve ailelerine hizmet vermesi ve sağlık alanında rol alan hemşire, ebe, doktor ve diyetisyen, odyometri uzmanları vb. günlük çalışma yaşamlarında sık sık strese neden olacak olaylara maruz kalmaları nedeniyle, diğer iş alanlarından farklılık göstermektedir. Sağlık hizmetleri içerisinde hemşireler, iş ortamında baskı altında kalmakta ve büyük ölçüde stres yaşamaktadırlar. Bu durumun birçok sebebi vardır. Yapılan çalışmalardan elde edilen sonuçlara göre bu sebeplerin başında, iş yükü fazlalığı, rol belirsizliği, duygusal destek olma gereksinimi, sağlık hizmetlerinde karşılaşılan sorunlar, mesleki bağımlılık, maaşların yeterli olmaması, yükselme, gelişme ve ödüllendirme sistemlerinin yetersiz olması, mesleğin imajı ve özgüven eksikliği gibi etmenler gelmektedir [1,2].

Hastanelerde çalışan hemşireler, değişen derecelerde psikolojik baskıya maruz kalmaktadır [3, 4]. $\mathrm{Bu}$ psikolojik baskının, hasta güvenliği, kontrol kaybı ve sağlık ekibi üyeleri ile kurumlar arasındaki iletişimsizlik gibi konularda hemşireliğin sonuçları üzerinde etkili olduğu düşünülmektedir [5]. Ağır stresli koşullar altında çalışmanın diğer olumsuz sonuçları, işe devamsızlık ve personel sirkülasyonu ile fiziksel ve psikolojik problemleri içermektedir [6,7].

$\mathrm{Bu}$ psikolojik stresörlere tepki hemşireler arasında farklıdır; bazıları baskıya uyum sağlarken, diğerleri bunu ihmal edebilir ve sonuçlara dikkat etmeden çalışmaya devam edebilir [8]. Bazı hemşireler de işe gitmeyi burakabilirler [3]. $\mathrm{Bu}$ nedenle, hemşireleri desteklemek ve performanslarını iyileştirmek ve ihtiyaçlarını karşılamak için çalışma ortamlarını geliştirmek önemlidir.

Literatür, bazı bölümlerde çalışan hemşirelerin diğer bölümlerdeki hemşirelerden daha fazla psikolojik strese maruz kaldıklarını göstermektedir [5,9-11]. Bu ortamlarda çalışmak duygusal olarak acı çekme şeklinde olabilmektedir [12]. Pek çok hemşirenin hastaları ölünce kendilerini keder duygularından ayırması bir sorundur [12-14]. İş yerinde personel sıkıntısı ve hemşirelerin yüksek yaşam beklentileri ve kronik hastalıklar ile başa çıkmadaki eksikliği, hemşirelerin hala rollerini tanımladıkları medikal ağırlıklı bir sağlık ortamı ile ilgili sorunlar söylenebilir. Ayrıca, beklenen bir sistemde kaynak eksikliği, yüksek bir mükemmellik standard1, hemşirelerin uğraştığ 1 ortak sorunlar olarak düşünülmelidir $[15,16]$. Bu psikolojik stresörlerin memnuniyet düzeylerini azaltması ve hastalara sunulan sağlık hizmetlerinin kalitesini etkilemesi beklenmektedi.

Psikolojik sıkıntı düzeyleri bir ülkeden diğerine ve bazen aynı ülkenin bölgeleri arasında farklılık göstermektedir $[17,18,19]$. Hemşirelerin yaş, medeni durum ve deneyim gibi demografik özellikleri arasındaki sıkıntı düzeylerinde de farklılıklar vardır [17, 20]. Sağlıklı bir psikolojiye sahip olmak hemşirelerin tatmin edici ve yüksek moral ortamında çalışmasına yardımcı olacaktır $[11,21]$. Hemşireler için iyi bir psikolojik istikrar elde etmek için, bazı konuların dikkate alınması gerekir; hemşireleri takdir etme, ihtiyacına saygı duymak, rahat bir çalışma ortamı sağlamak, başarı ve kendini gerçekleştirme ihtiyacını ele almak gerekir [3,21]. Uzun süreler stres altında çalışmak, çalışanlarda psikososyal sorunlara sebep olmaktadır [21]. Hemşirelik mesleği insanlarla ilişkiye dayanan bir meslek olduğu için; bedensel, ruhsal ve sosyal yönden iyilik hali içinde olan meslek üyelerine daha fazla ihtiyaç duyar.

Hemşirelerin yaşadıkları psikososyal sorunlardan yola çıkarak, bu çalışma hemşirelerin psikososyal sorunlarının ve stresle başa çıkma tarzlarının belirlenmesi amacıyla yapıldı.

\section{Mataryel ve Metot \\ 2.1 Araştırmanın Evreni}

Araştırmanın evrenini Menemen Devlet Hastanesi'nde görev yapan toplam 217 hemşire oluşturmaktadır.

\subsection{Araştırmanın Örneklemi}

Araştırmada herhangi bir örneklem seçimi tekniğine başvurulmamış olup evrenin tamamı örnekleme dahil edilmiştir. Araştırmaya katılmayı kabul eden ve dahil olma kriterlerini karşılayan 184 hemşire örneklemi oluşturdu. Araştırmaya katılan 184 hemşire evrenin \%84.7' sini oluşturmuştur.

\subsection{Veri Toplama Yöntemi}

Araştırma, hemşirelerde görülen psikososyal sorunların ve stresle başa çıkma tarzlarının belirlemek amacıyla planlanmış tanımlayıcı tipte bir çalışmadır. Araştırma yüz yüze görüşülerek, hemşirelere araştırmanın amacı açıklanmış yazılı gönüllü onam alınmıştır. 


\subsection{Veri Toplama Araçları}

Araştırma formları üç bölümden oluşmaktadır. Birinci bölüm; hemşirelerin sosyo-demografik özelliklerini içeren bilgi formu, ikinci bölüm; Hastane Anksiyete Depresyon Ölçeği (HAD) ve üçüncü bölüm; Stresle Başa Çıkma Tarzları Ölçeği (SBTÖ) yer almıştır.

-Kişisel Bilgi Formu: Hemşirelerin, sosyodemografik özelliklerini (cinsiyet, yaş, mezun olunan okul, hastalık durumu, psikososyal desteğe ihtiyaç duyma durumu vs.) belirlemek amacıyla ilgili literatür doğrultusunda hazırlanan 15 sorudan oluşan bir formdur.

-Hastane Anksiyete Depresyon Ölçeği (HAD): Zigmond ve Snaith (1983) tarafindan hastada anksiyete ve depresyon yönünden riski belirlemek, düzeyini ve şiddet değişimini ölçmek için geliştirilmiştir [22]. Ölçeğin Türkiye'de geçerlilik güvenilirlik çalışması Aydemir ve ark. (1994) tarafindan yapılmıştır [23]. Tanı koymak amaçlı değil anksiyete ve depresyonu risk grubunu belirlemek için kullanılır. Toplam 14 sorudan oluşmaktadır; yedisi (tek sayılar) anksiyeteyi ve yedisi (çift sayılar) depresyonu ölçmektedir. Yanıtlar dörtlü Likert biçiminde ve 0-3 arasında puanlanmaktadır. Ölçekte her maddenin puanlaması farklıdır. 1., 3., 5., 6., 8., 10., 11. ve 13. maddeler giderek azalan şiddet gösterirler ve puanlama $3,2,1,0$ biçimindedir. Öte yandan 2., 4., 7., 9., 12. ve 14. maddeler ise $0,1,2,3$, biçiminde puanlanırlar. Anksiyete alt ölçeği için 1., 3., 5., 7., 9., 11. ve 13. maddeler toplanırken; depresyon alt ölçeği için 2., 4., 6., 8., 10., 12. ve 14. Maddelerin puanları toplanır. Hastaların her iki alt ölçekten alabilecekleri en düşük puan 0 , en yüksek puan 21 'dir. HAD' in Türkçe formunun kesme noktaları anksiyete alt ölçeği (HAD-A) için 10, depresyon alt ölçeği (HADD) için 7 olarak saptanmıştır. Cronbach alfa katsayısı anksiyete alt boyutu için 0,8525, depresyon alt boyutu için 0,7784 olarak belirlenmiştir (Aydemir ve ark. 1994). Bizim çalışmamızda cronbach alfa katsayısı anksiyete alt boyutu için 0,80 , depresyon alt boyutu için 0,81 olarak belirlendi.

-Stresle Başa Çıkma Tarzları Ölçeği (SBTÖ): Folkman ve Lazarus tarafından geliştirilen Orijinal adı "Ways of Coping Inventory (WCI)/ Başa çıkma Yolları Envanteri" olan ölçekte bireylerin genel veya belirgin stres durumları ile başa çıkmak için kullandıkları yolları belirlemek amaçlanmıştır. Ölçeğin ülkemizde geçerlik ve güvenirlik çalışması 1991 yılında Siva, 1995 yılında Şahin ve Durak tarafından gerçekleştirilmiştir [24]. Bu araştırmada 1995 yılında Şahin ve Durak tarafından gerçekleştirilen ölçek kullanıldı. Ölçek Stresle Başa Çıkma Tarzları Ölçeği (SBTÖ) adı ile kullanılmaya başlanmıştır. SBTÖ duruma yönelik dörtlü likert tipi 30 madde içermektedir Ölçek, likert tipinde 0-3 arasında derecelendirmeyi gerektirmektedir $(0=\% 0,1=\% 30,2$ $=\% 70$ ve $3=\% 100$ ). 9. madde (İçinde bulunduğum kötü durumun kimse tarafından bilinmesini istemem) ise ters şekilde puanlanmaktadır $(3=\% 0,2=\% 30,1=$ $\% 70,0=\% 100)$. Alt boyutlara ayr1 toplam puanlar verilmekte ve genel toplam puan elde edilmemektedir.
Geliştirilen bu ölçekte, daha önce yapılan çalışmadan farklı olarak 5 temel faktör belirlenmiştir. Bunlar:

1. Kendine Güvenli Yaklaşım; yedi maddeden oluşan $(8,10,14,16,20,23,26)$ bu faktör, problemin önemi ve çözüm seçeneklerini değerlendirme, çözümde temkinli ve planlı olma; durumu değiştirmeye yönelik aktif, mantıklı ve bilinçli çabaları vurgulamaktadır.

2. İyimser Yaklaşım; hem probleme hem de duygulara yönelik boyutu olan bir faktördür. Olaylara daha hoşgörülü ve iyimser bakma, sorunları daha sakin ve gerçekçi bir şekilde değerlendirmeyi yansıtan bu yaklaşım beş maddeden oluşmaktadır $(2,4,6,12,18)$.

3. Kendine Güvensiz Yaklaşım; olaylar ya da sorunlar karşısında enerjinin büyük bir kısmını problemi çözmeye değil duygulara, başka kaynaklara dayandırmayı ifade eder. Toplam sekiz maddeden oluşmaktadır $(3,7,11,19,22,25,27,28)$.

4. Boyun Eğici Yaklaşım; altı maddeden $(5,13,15,17$, 21, 24) oluşmaktadır. Kaderci bir yaklaşımla kendini çaresiz hissetme, çözümü doğaüstü güçlerde aramayı vurgular.

5. Sosyal Destek Arama Yaklaşımı; sorunları başkalarıyla paylaşma, çözüm için başkalarından yardım istemeyi içeren bu yaklaşımda, sosyal destek aramanın probleme ve duygulara dönük olarak iki boyutu vardır. $\mathrm{Bu}$ yaklaşım biçimi dört maddeden $(1,9,29,30)$ oluşmaktadır.

\subsection{Araştırmanın Etik Boyutu}

Araştırma için Manisa Celal Bayar Üniversitesi Tıp Fakültesi Sağlık Bilimleri Etik Kurulu (Karar No: 07.03.2018/20.478.486) ve İzmir İl Sağlık Müdürlüğünden yazılı izinler alınmıştır. Ayrıca ölçeklerin kullanılması konusunda ölçek sahiplerinden ilgili izinler alınmıştır.

\subsection{Verilerin Analizi}

Araştırmada verilerin analizi için bilgisayar ortamında SPSS for Windows 15.0 paket programı kullanıldı. Verilerin değerlendirmesinde demografik özellikleri tanımlamak için sayı yüzde; demografik özelliklerle ölçek ortalama puan arasındaki ilişkiyi değerlendirmek için Kolmogorov Simirnov normallik testi sonucunda verilerin normal dağılmadığı tespit edilmiş olup, normal dağılım göstermeyen verilerde Mann Whitney $U$, Kruskal Wallis Testi; ölçeklerin ortalama puanları arasındaki ilişkiyi incelemek için Spearman korelasyon analizi kullanıldı.

\section{Bulgular \\ 3. 1 Hemşirelerin Demografik Özellikleri}

Hemşirelerin demografik özellikleri incelendiğinde; hemşirelerin \%94' ünün kadın, yaş ortalamasının $39,07 \pm 7,26$ olduğu, \%52,7' $\operatorname{sinin} 39$ yaş üstünde, $\% 62,5^{\prime}$ inin lisans ve üstü mezunu olduğu, \%60,3' ünün hastalığının olmadı̆̆ı, \%51.1'inin dahiliye bölümünde çalıştığ 1 belirlendi (Tablo 1).

\subsection{Hemşirelerin Mesleki Özellikleri}

Hemşirelerin mesleki özellikleri incelendiğinde; \%51,1' inin çalışma yılının 18 yıl üstünde olduğu, \%95,1' inin servis hemşiresi olarak çalıştı̆̆ $, \% 82,6$ ' sının mesleğini 
severek yaptığı, \%49,5'inin psikososyal açıdan desteğe ihtiyaç duyduğu belirlendi (Tablo 2).

Tablo 1. Hemşirelerin Demografik Özellikleri $(\mathrm{n}=184)$

\begin{tabular}{|c|c|c|}
\hline Özellikler & $\mathbf{n}$ & $\%$ \\
\hline \begin{tabular}{|l|} 
Cinsiyet \\
Kadin \\
Erkek \\
\end{tabular} & $\begin{array}{c}173 \\
11 \\
\end{array}$ & $\begin{array}{c}94.0 \\
6.0 \\
\end{array}$ \\
\hline $\begin{array}{l}\text { Yaş } * 39.07 \pm 7.26 \quad(\min -\max : \\
21.00-62.00) \\
39 \text { yaş ve altı } \\
39 \text { yaş üstü }\end{array}$ & $\begin{array}{l}87 \\
97\end{array}$ & $\begin{array}{l}47.3 \\
52.7\end{array}$ \\
\hline $\begin{array}{l}\text { Ĕgitim durumu } \\
\text { Sağlik lisesi ve ön lisans } \\
\text { Lisans ve üstü } \\
\end{array}$ & $\begin{array}{c}69 \\
115 \\
\end{array}$ & $\begin{array}{l}37.5 \\
62.5 \\
\end{array}$ \\
\hline $\begin{array}{l}\text { Hastalık durumu } \\
\text { Evet } \\
\text { Hayır } \\
\end{array}$ & $\begin{array}{c}73 \\
111 \\
\end{array}$ & $\begin{array}{l}39.7 \\
60.3 \\
\end{array}$ \\
\hline $\begin{array}{l}\text { Çalıştığı Klinik } \\
\text { Dahiliye bölüm } \\
\text { Cerrahi bölüm } \\
\text { Diğer (Poliklinik. kan alma. } \\
\text { yönetim vs) }\end{array}$ & $\begin{array}{l}96 \\
59 \\
29\end{array}$ & $\begin{array}{l}51.1 \\
33.1 \\
15.8\end{array}$ \\
\hline Toplam & 184 & 100.0 \\
\hline
\end{tabular}

*Aritmetik ortalama \pm standart sapma

Tablo 2. Hemşirelerin Mesleki Özellikleri $(n=184)$

\begin{tabular}{|c|c|c|}
\hline \multicolumn{3}{|l|}{\begin{tabular}{|l|l} 
Özellikler \\
\end{tabular}} \\
\hline \multicolumn{3}{|l|}{ Çalıșma yılı } \\
\hline 18 y1l ve alt1 & 90 & 48.9 \\
\hline 18 yıl üstü & 94 & 51.1 \\
\hline \multicolumn{3}{|l|}{ Çalıştığı pozisyon } \\
\hline Servis Hemşiresi & 175 & 95.1 \\
\hline Servis Sorumlu Hemşiresi & 9 & 4.9 \\
\hline \multicolumn{3}{|l|}{ Mesleği severek yapma durumu } \\
\hline Evet & 152 & 82.6 \\
\hline Hayır & 32 & 17.4 \\
\hline $\begin{array}{l}\text { İşyerinde psikososyal açıdan } \\
\text { desteğe ihtiyaç duyma }\end{array}$ & 91 & 49.5 \\
\hline Evet & 93 & 50.5 \\
\hline Hayır & & \\
\hline
\end{tabular}

\subsection{Hemşirelerin İş Yerinde Yaşadığı Psikososyal} Sorunlar

Hemşirelerin iş yerinde yaşadığ 1 psikososyal sorunlarınının sözel ifadeleri incelendiğinde; en çok iş yükü, vardiyalı çalışma, çatışma sorunu olduğu belirlendi. $\% 51,3$ ' ünün iş yükünden dolayı zorlandıkları, \%17,5'inin vardiyalı çalışma, \%15,6'sının çatışma sorunu yaşadığı, \%13,6'sının fiziksel sorun, $\% 12,3$ 'ünün hasta ve hasta yakını ile sorun, $\% 9,7$ 'sinin yönetim eksikliği sorunu yaşadığı belirlendi (Tablo 3).

3.4 Hemşirelerin Hastane Anksiyete Depresyon Ölçeği Puan Ortalamalarının Dağılımı ve Risk Durumları

Tablo 4'de hemşirelerin hastane anksiyete depresyon ölçeği puan ortalamaları dağılımları incelendiğinde; anksiyete alt boyutu ortanca puanı 1,07 (ÇAA:0,75), depresyon alt boyutu ortanca puanı 0,85 (ÇAA:0,82) olarak saptandı ve hemşirelerin hastane anksiyete depresyon ölçeği risk durumları değerlendirildiğinde; anksiyete ve depresyon alt boyutu risk değerlendirmesinde hemşirelerin \%100'ünün risk sınırında olmadığı belirlendi (Tablo 4).

Tablo 3. Hemşirelerin İş Yerinde Yaşadığı Psikososyal Sorunlar $(\mathrm{n}=154 *)$

\begin{tabular}{|l|c|c|}
\hline Değişkenler & n & $\%$ \\
\hline İş Yükü & 79 & 51.3 \\
Evet & 75 & 48.7 \\
Hayır & 30 & \\
Yanıt Yok & & \\
& & \\
\hline Çatışma & & \\
Evet & 24 & 15.6 \\
Hayır & 130 & 84.4 \\
\hline Vardiyalı çalışma & & \\
Evet & 27 & 17.5 \\
Hayır & 127 & 82.5 \\
\hline Yönetim eksikliği & & \\
Evet & 15 & 9.7 \\
\hline Hayır & 139 & 90.3 \\
\hline Hasta ve hasta yakınları & & \\
Evet & 19 & 12.3 \\
\hline Hayır & 135 & 87.7 \\
\hline Fiziksel koşullar & & \\
Evet & 21 & 13.6 \\
Hayır & 133 & 86.4 \\
\hline
\end{tabular}

*İş yerinde en çok zorlayan şey değişkeni kategorize edildi ve örneklem sayısı $n=154$ olarak belirlendi. 30 kişi sorulara yanıtsız bıraktı.

\subsection{Hemşirelerin Stresle Başa Çıkma Tarzları Ölçeği} Puan Ortalamalarının Dağılımı

Tablo 5'de hemşirelerin stresle başa çıkma tarzları ölçeği puan ortalamaları dağılımları kendine güvenli yaklaşım alt boyutu ortanca puanı 2,14 (ÇAA:0,86), iyimser yaklaşım alt boyutu ortanca puanı 2,00 (ÇAA:0,60), kendine güvensiz yaklaşım alt boyutu ortanca puanı 1,12 (ÇAA:0,75), boyun eğici yaklaşım alt ölçeğinde ortanca puanı 1,00 (ÇAA:0,67), sosyal destek arama yaklaşımı alt ölçeğinde ortanca puanı 2,00 (ÇAA:0,75) olarak bulundu (Tablo 5).

Hemşirelerin mesleği severek yapmaları ve psikososyal desteğe ihtiyaç duyma ile anksiyete/depresyon alt boyutu ortanca puanları arasında anlamlı fark olduğu $(p<0,05)$, "evet" yanitı verenlerin, "hayır" yanitı verenlerin anksiyete/depresyon alt boyutu ortanca puanlarından daha düşük olduğu belirlendi. Hemşirelerin hastalığa sahip olma durumları ile anksiyete/ depresyon alt boyutları puan ortalamaları arasında anlamlı fark olduğu $(\mathrm{p}<0,05)$, "hayır" diyen hemşirelerin anksiyete/ depresyon alt boyutu, "evet" diyen hemşirelere göre daha düşük olduğu saptand1. Hemşirelerin demografik özelliklerinden cinsiyet, yaş grubu, eğitim durumu, birimden memnuniyet, çalışılan pozisyon, çalışma yılı, birimde çalışma yılı, çalışma şekli ve iş yerinde en çok zorlandıkları durumlar ile anksiyete ve depresyon alt boyut ortanca puanları arasında anlamlı bir ilişki olmadığı belirlendi ( $p>0,05)$. 
Tablo 4. Hemşirelerin Hastane Anksiyete Depresyon Ölçeği Puan Ortalamalarının Dağılımı ve Risk Durumları $(n=184)$

\begin{tabular}{|c|c|c|c|c|}
\hline Hastane Anksiyete Depresyon Ölçeği & Ortalama & Ortanca & ÇAA* & Min-Maks \\
\hline Anksiyete alt boyutu & 1.10 & 1.07 & 0.75 & $0.00-2.57$ \\
\hline Depresyon alt boyutu & 0.95 & 0.85 & 0.82 & $0.00-3.00$ \\
\hline
\end{tabular}

*ÇAA: Çeyrekler arası aralık

Tablo 5. Hemşirelerin Stresle Başa Çıkma Tarzları Ölçeği Puan Ortalamalarının Dağılımı (n=184)

\begin{tabular}{|l|c|c|c|c|}
\hline $\begin{array}{l}\text { Stresle Başa Çıkma Tarzları Ölçeği } \\
\text { Alt Boyutları }\end{array}$ & Ortalama & Ortanca & ÇAA* & Min-Maks \\
\hline Kendine güvenli yaklaşım alt boyutu & 2.20 & 2.14 & 0.86 & $0.86-3.00$ \\
\hline İyimser yaklaşım alt boyutu & 1.93 & 2.00 & 0.60 & $0.40-3.00$ \\
\hline Kendine güvensiz yaklaşım alt boyutu & 1.15 & 1.12 & 0.75 & $0.00-2.38$ \\
\hline Boyun eğici yaklaşım alt boyutu & 1.01 & 1.00 & 0.67 & $0.00-2.67$ \\
\hline Sosyal destek arama yaklaşımı alt boyutu & 1.96 & 2.00 & 0.75 & $0.25-3.00$ \\
\hline
\end{tabular}

*ÇAA: Çeyrekler arası aralık

3.6 Hastane Anksiyete Depresyon Ölçeği ile Stresle Başa Çıkma Tarzları Ölçeği Alt Boyut Puan Ortalamalarının Karşılaştırılması

Hemşirelerin hastane anksiyete depresyon ölçeği alt boyutları ile stresle başa çıkma tarzları alt boyutları arasındaki ilişkiyi gösteren Spearman korelasyon analizi bulgularına göre; anksiyete alt boyutu ile kendine güvenli yaklaşım alt boyutu arasında negatif yönde orta $\left(r_{s}=-0,558, \quad p<0,01\right)$, iyimser yaklaşım alt boyutu arasında negatif yönde zayıf ilişki $\left(\mathrm{r}_{\mathrm{s}}=-0,456, \mathrm{p}<0,01\right)$, anksiyete alt boyutu ile kendine güvensiz yaklaşım alt boyutu arasında pozitif yönde orta $\left(r_{s}=0,531, p<0,01\right)$, boyun eğici yaklaşım alt boyutu arasında pozitif yönde zayıf ilişki $\left(\mathrm{r}_{\mathrm{s}}=0,327, \mathrm{p}<0,01\right)$ saptandı. Dolayısıyla, anksiyete alt boyutu puanlarındaki artış ile kendine güvenli yaklaşım ve iyimser yaklaşım alt boyutları puanlarında azalma olmakta, kendine güvensiz yaklaşım

Tablo 6. Hastane Anksiyete Depresyon Ölçeği ile Stresle Başa Çıkma Tarzları Ölçeği Alt Boyut Puan Ortalamalarının Karşılaştırılması

\begin{tabular}{|c|c|c|c|c|c|c|c|c|}
\hline & & 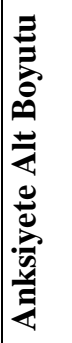 & 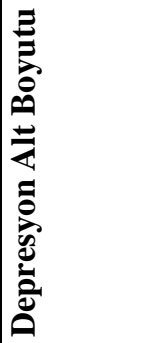 & 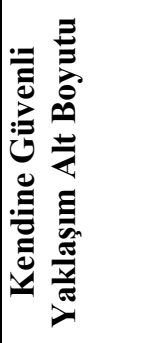 & 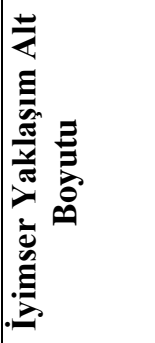 & 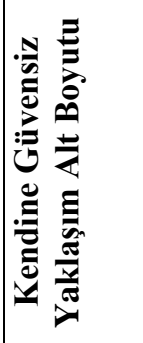 & 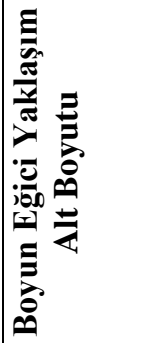 & 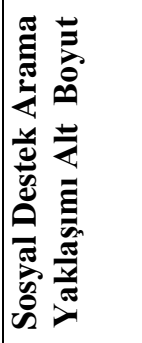 \\
\hline Anksiyete Alt Boyutu & $1_{\mathrm{S}}$ & - & $0.634 * *$ & $-0.558 * *$ & $-0.456 * *$ & $0.531 * *$ & $0.327 * *$ & -0.133 \\
\hline Depresyon Alt Boyutu & $\mathrm{r}_{\mathrm{s}}$ & - & - & $-0.587 * *$ & $-0.497 * *$ & $0.448 * *$ & $0.251 * *$ & $-0.190 * *$ \\
\hline
\end{tabular}

$* \mathrm{p}<0,05 * * \mathrm{p}<0,01 \mathrm{r}_{\mathrm{s}:}$ Spearman korelasyon testi değeri

\section{Tartışma}

Hasta ve aileleriyle birebir iletişim halinde olan hemşirelik meslek üyeleri bu grup içinde önemli bir grubu oluşturmaktadır. $\mathrm{Bu}$ çalışmanın sonuçları hemşireler arasında psikososyal sorunların çözümlenmesinde, hemşirelerin psikososyal sorunları fark etmeleri ve sorunlarla baş etme konusunda önemli olduğu düşünülmektedir. ve boyun eğici yaklaşım alt boyutları puanlarında ise artış olmaktadır.

Depresyon alt boyutu ile kendine güvenli yaklaşım alt boyutu arasında negatif yönde orta $\left(r_{s}=-0,587, p<0,01\right)$, iyimser yaklaşım alt boyutu arasında negatif yönde zayıf ilişki $\left(r_{s}=-0,497, p<0,01\right)$, sosyal destek arama yaklaşımı alt boyutu arasında negatif yönde çok zayıf ilişki $\left(r_{s}=-0,190, p<0,01\right)$, depresyon alt boyutu ile kendine güvensiz yaklaşım alt boyutu arasında pozitif yönde zayıf $\left(r_{s}=0,448, p<0,01\right)$, boyun eğici yaklaşım alt boyutu arasında pozitif yönde zayıf ilişki $\left(r_{s}=0,251\right.$, $\mathrm{p}<0,01)$ saptand1. Buna göre, depresyon alt boyutu puanlarındaki artış ile kendine güvenli yaklaşım, iyimser yaklaşım ve sosyal destek arama yaklaşımı alt boyutları puanlarında azalma olmakta, kendine güvensiz yaklaşım ve boyun eğici yaklaşım alt boyutları puanlarında ise artış olmaktadır (Tablo 6).
Hemşirelerin büyük çoğunluğunun çalıştığ memnun olduğu, hemşirelerin birimden memnun olma durumları ile olumlu başa çıkma tarzı olan iyimser yaklaşımı kullandığı belirlendi. Çalıştığı birimden memnun olanların daha iyimser, hoşgörülü yaklaştığ anlaşılmaktadır. Ayrıca mesleğini severek yapan hemşirelerin anksiyete ve depresyon puanlarının düşük olduğu ve olumlu başa çıkma tarzları kullandıkları saptandı. Mesleğini seven hemşirelerde depresyonun daha az görüldüğü, kendilerine güvenerek daha huzur 
içinde çalıştıkları düşünülmektedir. Araştırmanın yapıldığı hastanenin Batı bölgesi İzmir il merkezine yakın olması çalışanların ihtiyaçlarına yanıt vermesi açısından olumlu olduğu düşünülebilir. Hemşirelerin Türkiye'nin en büyük üç ilinden birinde yaşamaları; fizyolojik, psikolojik ve çevresel ihtiyaçlarını karşılamaları bakımından avantaj sağlamış olabilir.

Hemşirelerin herhangi bir hastalığa sahip olma durumları ile anksiyete ve depresyon puanları yüksek olduğu belirlendi. Hastalıkların varlığı bireylerde ağrı, uykusuzluk, konsantrasyon bozukluğu ve stresle başetme de zorluğa neden olabilmektedir. Hastalığın varlığı zor bir meslek olan hemşirelik mesleğini yaparken anksiyete ve depresyonun eşlik etmesini güçlendirdiği düşünülebilir.

Hemşirelerin işyerinde en çok zorlandıkları durumlardan iş yükü ve çatışma olduğu belirlendi ve anksiyete/depresyon alt boyutu ortanca puanları arasında anlamlı bir fark olmadığı belirlendi. Yapılan çalışmalarda çalışma bulgumuzla paralellik göstermekte ve hemşirelerin en fazla iş yükünden dolayı stres yaşadığı belirlenmiştir [25-28]. Yapılan yurt dışı çalışmalarda; her altı hemşireden birinin, mesleksel stres ve tükenmişlik [29], rol çatışması, iş / zaman baskısı, iş yükü, rol belirsizliği, yetersiz sosyal destek, yetersizlik gibi çeşitli stres faktörlerinden mustarip olduğunu göstermektedir. Stresi yönetmedeki başarısızlık, yorgunluk, duygusal tükenme, iş tatminsizliği, işten ayrılma niyeti ve kötü ruh sağlı̆̆ gibi birey üzerinde olumsuz sonuçlarla ilişkilidir [30]. Sürekli strese maruz kalmak, sadece hemşirelerin sağlığını olumsuz etkilemekle kalmadığı aynı zamanda personeli, hastaları etkilediği belirlenmiştir [31]. Diğer çalışmalarda; çalışma stresini daha yüksek tıbbi hata insidansı, olumsuz hasta olayları ve düşük hasta bakım kalitesi ile ilişkili olduğu saptanmıştır [32, 33]. Çalışma sonucumuzun literatürle uyumlu olduğu gözlenmiştir.

Hemşirelerin \%49,5' inin işyerinde psikososyal açıdan desteğe ihtiyaç duyduğu belirlendi. Hemşirelerin işyerinde psikososyal desteğe ihtiyaç duyma durumları ile anksiyete ve depresyon alt ölçekleri puan ortalamaları arasında anlamlı fark ilişki olduğu bulundu. Çalışma verilerine göre anksiyetesi yüksek olan hemşirelerin psikosoyal destek almaya istekli olduğu, anksiyetesi düşük olanların ise yardıma gereksinim duymadıkları anlaşılmaktadır. Kendine güvenli yaklaşıma sahip kişilerin de psikososyal desteğe ihtiyaç duyması, kendine güvensiz yaklaşıma sahip kişilerin ise desteğe ihtiyaç duymaması sonucu birbirini destekler nitelikte olmaktadır. İsveç'teki 1.417 hemşirenin bir grubu istihdamın ilk 5 y1lı boyunca mezuniyet sonrasında takip edilmiş ve ankete katılan her beş hemşireden birisinin mesleği bırakmayı planladığı bulunmuştur. Meslekten ayrılma niyetinin temel belirleyicisinin tükenmişlik düzeyi olduğunu bulunmuştur [34]. Uluslararası olarak, çalışmalar, hemşirelik iş gücü arasında yüksek oranda tükenmişlik ve stresle ilgili diğer durumları tutarlı bir şekilde rapor etmiştir [35-37]. Hemşirelerin tükenmişlik, anksiyete ve depresyon ve sekonder travmatik stres gibi strese bağlı durumları içerecek şekilde özellikle savunmasız olma koşulları yer almaktadır [21, 26, 35].

Çalıșmamızda hemşirelerin çoğunluğu dahiliye bölümünde çalıştığı belirlendi. Hemşirelerin stresle başa çıkmada en çok kendine güvenli yaklaşım, iyimser yaklaşım ve sosyal destek arama yaklaşımı kullandıkları bulundu. Özaltın ve Nehir, (2002) 'in Ankara ilinde bulunan yoğun bakım ünitelerinde çalışan hemşirelerle yaptıkları çalışma sonuçları ile benzerlik göstermektedir. Yunanistan' da psikiyatri hemşireleri ile yapılan bir çalışmada hemşirelerin stresle baş etmede en çok; probleme odaklanan başa çıkma stratejileri (pozitif yeniden değerlendirme, pozitif yaklaşım, problem çözme ve sosyal destek arama) psikiyatri hemşireleri tarafından kullanıldığı belirlenmiştir [38]. Onkoloji biriminde çalışan hemşireler arasında yapılan bir çalışmada, hemşirelerin stresle baş etmede en çok; kaçınma, sosyal destek arama, mesleki ve sosyal yaşamı dengeleme ve maneviyatı kullandıkları belirlenmiştir [39]. Çalışma sonuçlarının farklılıkları hemşirelerin çalıştıkları birimlerin etkilediği söylenebilir.

Hemşirelerin hastane anksiyete depresyon ile stresle başa çıkma tarzları alt boyutları arasındaki ilişkiyi gösteren analiz bulgularına göre; depresyonu olmayanların ve anksiyete düzeyi düşük olan kişilerin kendilerine güveninin fazla, iyimser, hoşgörülü, sakin bir tutum içerisinde olduğunu, depresyonu olanların ve anksiyete düzeyi yüksek olan kişilerin ise kendisine güvensiz, boyun eğici bir tutumda olduğu ve sosyal destek arama davranışı içerisinde olduğunu düşündürmektedir. Slovenya' da yapılan bir çalışmada; hemşireler kaçınma ve sorunlardan uzaklaşma gibi stresle başa çıkma konusunda duygu odaklı stratejiler kullandığı belirlenmiştir [40]. $\mathrm{Bu}$ sonuç çalışma sonucumuzu kismen desteklemektedir. Hastane içerisinde hemşirelerin ihtiyaç olan birimlere göre istihdam edilmeleri ve bireysel istekleri bu yüzden göz ardı edilebilmektedir. Bu durum, hemşirelerin stresle baş etmelerinde kendi klinik uygulamalarını değiştirmeye yetkili olmadıklarını ve durumu değiştiremedikleri için olduğu gibi kabul etmeleri gerekebilmektedir. Bunu yapmak daha rahat ve fazla çaba gerektirmez. İnkâr etmek, yüzleşmekten kaçınmak gibi durumlar günlük rutine etki edebilir bu yüzden stresle baş etmede boyun eğici yaklaşım söz konusu olabilmektedir.

\section{Sonuç}

Birimden memnun olma durumları ile iyimser yaklaşım başa çıkma tarzı arasında anlamlı ilişki olduğu belirlendi. Hemşirelerin işyerinde en çok zorlandıkları durumlardan iş yükü ve çatışma olduğu iyimser yaklaşım başa çıkma tarzı ile anlamlı fark olduğu belirlendi. Hemşireler mümkün olduğunca severek ve huzurlu çalıştıkları yerlerde istihdam edilmelidir. 
Hemşirelerin zor bir gruba hizmet vermesinden dolayı yıpranma durumları değerlendirilebilir. Hemşirelerin görev tanımları belirlenmeli ve iş yükünün hafifletilmesine yönelik hemşire alımlarının arttırılması, hemşire başına düşen hasta sayısının azaltılması gibi faaliyetler yapilabilir.

\section{Kaynaklar}

1. Görgülü, S. Hemşirelik ve anksiyete. Türk Hemşireler Dergisi, 1988, 38, 23-24.

2. Canbaz, S, Sünter, T, Dabak, Ş, Öz, H, Peşken, Y Hemşirelerde tükenmişlik sendromu, iş doyumu ve işe bağl gerginlik. Hemşirelik Forumu, 2005, 4, 30-34.

3. Barker, P. Psychiatric and mental health nursing: The craft of caring. Second Edition. Taylor \& Francis Group LLC. U.S 2008.

4. Seligman, M.E, Csikszentmihalyi, M. Olumlu psikoloji: Giriș New York, NY: Springer Hollanda, 2014, pp 279-298.

5. Toh, S.G, Ang, E, Devi, M.K. Systematic review on the relationship between the nursing shortage and job satisfaction, stress and burnout levels among nurses in oncology/haematology settings. Int $\mathrm{J}$ Evid Based Healthc. 2012, 10(2), 126-41.

6. Atindanbila, S, Abasimi, E, Anim, M.T. A Study of work related depression, anxiety and stress of nurses at pantang hospital in ghana. 2012, 2(9).

7. Russell, M. Lateral violence among new graduate nurses. nursing theses and capstone projects .2016, 239.

8. Lievrouw, A, Vanheule, S, Deveugele, M, et al. Coping with moral distress in oncology practice: nurse and physician strategies. Oncol Nurs Forum 2016, 43(4), 505-12.

9. Escot, C, Artero, S, Catherine, G, Boulenger, J.P, Ritchie, K. Stress levels in nursing staff working in oncology. stress and health, 2001, 17, 273-279.

10. Faria, A.P, Maia, E. Nursing professionals anxiety and feelings in terminal situations in oncology. Revista latinoamericana de enfermagem. 2007, 15, 1131-7.

11. Uitterhoeve, R, Bensing, J, Dilven, E, Donders, R, DeMulder P, Van, A.T. Nurse-patient communication in cancer care: does responding to patient's cues predict patient satisfaction with communication. Psychooncology. 2009, 18(10), 1060-8.

12. Tuna, R, Baykal, Ü. Nitel bir çalıșma: onkoloji hemşirelerinin çalışma koşulları ve bilgi düzeylerinin çalışan güvenliğ açısından belirlenmesi. Uluslararası Hemșirelik ve Klinik Uygulamalar Dergisi, 2017, 4, 5.

13. Dhotre, K.B, Adams, S.A, Hebert, J.R, Bottai, M, Heiney, S.P. Oncology nurses' experiences with patients who choose to discontinue. Cancer Chemotherapy. 2016, 43(5), 617-623.

14. Nelson, M. Profesyonel hemşirelik uygulaması eğitimi: geleceğe geriye bakıș. Hemșirelikte Çevrimiçi Sorunlar Dergisi, 2002,7( 3).

15. Greenglass, E.R, Burke, R.J. Hospital downsizing, individual resources, and occupational stressors in nurses. Anxiety Stress and Coping, 2000, 13, 371-390.

16. WHO. World Report on Violence and Health. Geneva (Switzerland), 2002, pp 1-21.

17. Cheung, E.F.C. Depression, anxiety and symptoms of stress among Hong Kong nurses: A cross-sectional study. International Journal of Environmental Research and Public Health, 2015, 12(9), 11072-11100.

18. Schmidt, D. R. C. Anxiety and depression among nursing professionals who work in surgical units. Revista Da Escola De Enfermagem USP, 2011, 45(2), 475-481.

19. Zandi A. Frequency of depression, anxiety and stress in military

20. Ko W, Kiser-Larson N. Stress levels of nurses in oncology outpatient units. Clinical Journal of Oncology Nursing, 2016, 20(2), 158-164.

21. Wu, S, Singh-Carlson, S, Odell, A, Reynolds, G, Su, Y Compassion fatigue, burnout, and compassion satisfaction among oncology nurses in the United States and Canada. Oncology Nursing Forum, 2016, 43.
22. Zigmond, A.S, Snaith, R.P. The hospital anxiety and depression scale. Acta Psychiatr Scand, 1983, 67(6), 361-70.

23. Aydemir, Ö, Güvenir, T, Küey, L, Kültür, S. Hastane Anksiyete ve depresyon ölçeğinin türkçe formunun geçerlik ve güvenilirlik çalışması. Türk Psikiyatri Dergisi, 1997, 8(4), 280-287.

24. Şahin, N, Durak, A. Stresle başa çıkma tarzları ölçeği: üniversite öğrencileri için uyarlanması. Türk Psikoloji Dergisi, 1995, 10(34), 56-73

25. Özaltın, G, Nehir, S. Ankara ilindeki hastanelerin yoğun bakım ünitelerinde çalışan hemşirelerin iş ortamındaki stres etkenleri ve kullandıkları başetme yöntemlerinin belirlenmesi. Atatürk Üniversitesi Hemşirelik Yüksekokulu Dergisi, 2007, 10,3 .

26. Garrosa, E, Moreno-Jime'nez, B, Liang, Y, Gonza'lez J.L. The relationship between socio-demographic variables, job stressors, burnout, and hardy personality in nurses: An exploratory study. International Journal of Nursing Studies, 2008, 45, 418-427.

27. Önder, E, Aybas, M. Hemşirelerin stres seviyesine etki eden faktörlerin öncelik sırasının çok kriterli karar verme tekniği ile belirlenmesi. Optimum Ekonomi ve Yönetim Bilimleri Dergisi, 2010, 1(1).

28. Çirik, A. Yoğun bakım ünitesinde çalışan hemşirelerin stres faktörlerinin belirlenmesine ve stres yönetimlerine ilişkin bir araștırma. G.Ü. İşletme Ana Bilim Dalı Hastane İșletmeciliği Bilim Dalı. Yüksek Lisans Tezi, Ankara, 2018.

29. Van, B.P, Adriaenssen J, Dilles, T, Martens D, Van R.B, Timmermans, O. Impact of Role-, Job- and Organizational Characteristics on Nursing Unit Managers' Work. Related Stress and Well-Being, 2014, 70(11), 2622-33.

30. McVicar, A. Scoping the common antecedents of job stress and job satisfaction for nurses (2000-2013). Using the Job Demands-resources Model of Stress. 2016, 24(2), 112-36.

31. Shirey, M.R, Ebright, P.R, McDaniel, A.M. Nurse manager cognitive decision-making amidst stress and work complexity. 2013, 21(1), 17-30.

32. North, N, Leung, W, Ashton, T, Rasmussen, E, Hughes, F, Finlayson, M. Nurse turnover in new zealand: costs and relationships with staffing practises and patient outcomes. Journal of Nursing Management, 2013, 21(3), 419-428.

33. Hayes, L.J, O'Brien-Pallas, L, Duffield, C, et al. Nurse Turnover: A Literature Review-an Update. International Journal of Nursing Studies. 2012, 49(7), 887-905.

34. Rudman, L.A, Fetterolf, J.C, Sanchez, D.T. What motivates the sexual double standard? More support for male versus female control theory. Personality and Social Psychology Bulletin, 2013, 39, 251-263.

35. Ray, S.L, Wong, C, White, D, Heaslip, K. Compassion satisfaction, compassion fatigue, worklife conditions and burnout among frontline. Mental Health Care Professionals, 2013, 19, 255-267.

36. Hegney, D.G, Craigie, M, Hemsworth, D, et al. Compassion satisfaction, compassion fatigue, anxiety, depression and stress in registered nurses in Australia: Study 1 Results, Journal Nursing Manage, 2014, 22, 506-518.

37. Craigie M, Osseiran-Moisson R, Hemsworth D, et al. The influence of trait negative affect and compassion satisfaction on compassion fatigue in Australian. Nurses. Psychol Trauma, 2016, 8(1), 88-97.

38. Tsaras, K, Daglas, A, Mitsi, D, et al. A cross-sectional study for the impact of coping strategies on mental health disorders among psychiatric nurses. Health Psychol Res, 2018, 8, 6(1), 7466.

39. Partlak, G.N, Üstün, B, Serçekuş, A.P, Büyükkaya, D. Secondary traumatic stress experiences of nurses caring for cancer patients. Int J Nurs Pract. 2018, 18.

40. Bregar, B, Skela-Savič, B, Kores, Plesničar, B. Cross-sectional study on nurses' attitudes regarding coercive measures: the importance of socio-demographic characteristics, job satisfaction, and strategies for coping with stress. BMC Psychiatry. 2018, 4, 18(1), 171. 
http://edergi.cbu.edu.tr/ojs/index.php/cbusbed

isimli yazarın CBU-SBED başlıklı eseri bu

Creative Commons Alıntı-Gayriticari4.0

Uluslararası Lisansı ile lisanslanmıştır.

\section{(c) (7) (8)}

